
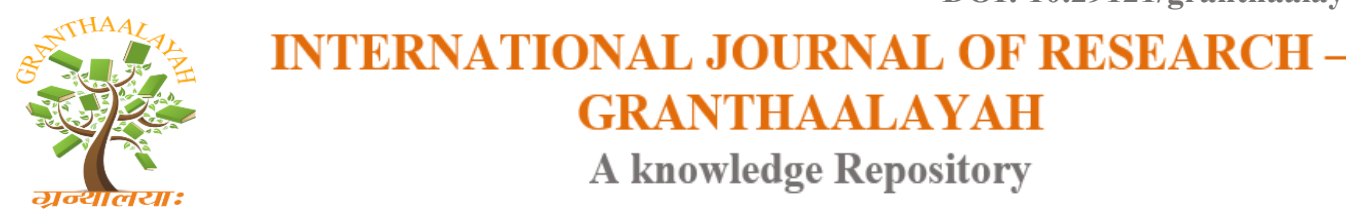

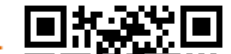

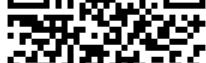
.

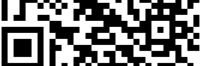

Science

\title{
COPING PATTERN AMONG THE CAREGIVERS OF PERSONS LIVING WITH CANCER
}

\author{
Dr. Thirumoorthy ${ }^{* 1}$, Dr. P. Saraswati Devi ${ }^{2}$, Dr. K. Thennarusu ${ }^{3}$ \\ ${ }^{* 1}$ Additional Professor, Dept. of Psychiatric Social Work, National Institute of Mental Health \\ and Neuro Sciences (NIMHANS), Bangalore-29, INDIA \\ ${ }^{2}$ Professor \& Head, Dept. of Palliative Care \& Anesthesiologist, Kidwai Memorial Institute of \\ Oncology (KIDWAI), Bangalore, INDIA \\ ${ }^{3}$ Professor, Dept. of Biostatistics, National Institute of Mental Health and Neuro Sciences \\ (NIMHANS), Bangalore-29, INDIA
}

\begin{abstract}
Cancer is a class of diseases in which a cell or a group of cells displays uncontrolled growth, invasion and sometimes metastasis. These three malignant properties of cancer differentiate them from being tumors, which are self-limited and do not invade or metastate. Most cancers form a tumor but some like leukemia do not. The branch of medicine concerned with study diagnosis, treatment and prevention of cancer is oenology. Cancer can affect people of all ages with the risk of most types increasing with age cancers are primarily an environmental disease due to lifestyle and environmental factors and due to genetics. The present study consisted of 300 caregivers of persons with cancer was selected based on simple random sampling, and with inclusion and exclusion criteria. Those patients satisfying the inclusion and exclusion criteria and attending both outpatient and inpatient services of cancer specialty hospital in KIDWAI Bangalore, Karnataka were selected randomly. The data was collected from the patients \& caregivers of persons living with cancer who fulfill the inclusion/exclusion criteria were taken up for the study after their consent. The Coping Check List (Rao et al, 1989) was administered to understand the coping pattern. The interviews and the instruments were administered by research experts. This study concluded that there was poor coping were found in female caregivers, illiterate caregivers, caregivers of cancer patients underwent surgery, the person's not hearing about cancer, and other religion caregivers. So, it is imperative to design suitable intervention strategies to enhance the coping and other psychosocial issues of caregivers of patients living with cancer.
\end{abstract}

Keywords:

Coping pattern, Caregivers, Cancer.

Cite This Article: Dr. Thirumoorthy, Dr. P. Saraswati Devi, and Dr. K. Thennarusu, "COPING PATTERN AMONG THE CAREGIVERS OF PERSONS LIVING WITH CANCER" International Journal of Research - Granthaalayah, Vol. 4, No. 2 (2016): 75-86. 


\section{INTRODUCTION}

Cancer is currently the cause of $12 \%$ of all deaths worldwide. In approximately 20 years' time, the number of cancer deaths annually will increase from about 6 million to 10 million. In India it is estimated that there are 2 to 2.5 million cancer patients at any given point of time with about 0.7 million new cases coming every year and nearly half die every year. Two-third of the new cancers is presented in advance and incurable stage at the time of diagnosis. More than $60 \%$ of these affected patients are in the prime of their life between the ages of 35 and 65 years. With increasing life expectancy and changing lifestyles concomitant with development, the number of cancer cases will be almost three times in the current number. WHO has estimated that $91 \%$ of oral cancers in South-East Asia are directly attributable to the use of tobacco and this is the leading cause of the oral cavity and lung cancer in India (Report on National Care Control Program, 2008). Modern hospital care has led to increase in home based palliative care services, with informal caregivers assuming responsibility for the majority of care. In response, health policy emphasizes the provision of palliative care services in which both patient and care receive adequate support throughout illness and death. While the emotional needs of cares have been extensively researched, their practical needs with respect to the provision of physical care are yet to receive systematic attention. Home based palliative care services have been insufficiently focused on assisting informal caregiver's adequate-practical nursing skills. Professional advice represents a potentially effective method of increasing carers confidence and their ability to undertake practical aspects home-based care. Evidence suggests that nurses and other health providers may better assist home based carers by providing the information and skills training necessary to facilitate this. This may necessitate the involvement of carers in the design and testing of new educational interventions. Caregiver includes it may be the spouse of the patient, or relative, or maybe the friends, or the health care representatives caregivers usually suffer with anxiety while caring cancer patient due to appreciably severe symptoms and suffering of cancer closeness with client and impending death of the patient.

\section{COPING AMONG CAREGIVERS OF PERSON LIVING WITH CANCER}

The association between religious coping, mental health and the caring experience, as well as potential explanatory mechanisms, among 162 informal caregivers of terminally ill cancer survivors was investigated. Regression analyses indicated that, controlling for sociodemographic variables, more use of positive religious coping strategies was associated with more burden, yet, also more satisfaction. In contrast, more use of negative religious coping strategies was related to more burden, poorer quality of life and less satisfaction, and correlated with an increased likelihood of Major Depressive Disorder and Anxiety disorders (Pearce, Singer, \& Prigerson, 2006).

\section{SCOPE AND OBJECTIVES}

Cancer is a major public health problem of the world. Diagnosis of cancer has a significant impact not only on patient, but also on their family caregivers. Therefore cancer has a substantial impact on both patients and families. Hence the present study will help us in formulating family intervention improve their coping pattern of caregivers of persons with cancer. The purpose of the present study was to examine coping pattern of caregivers of persons with cancer. 


\section{OBJECTIVES}

To find out the socio demographic characteristics of persons with cancer and their caregivers

To find out the relationship between socio demographic characteristics and Coping pattern of caregivers of persons with cancer

\section{RESEARCH METHODOLOGY}

The present study has adopted a descriptive research design to describe the variables associated with various psychosocial aspects of caregivers of persons with cancer. It aims at describing the variables associated with the psychosocial correlates and problems of cancer patients with caregivers due to cancer and its treatments. The variables ranged from socio-demographic details and quality of life. The caregivers of patients diagnosed with cancer (acute, middle or end of life phase of cancer) who are admitted in cancer specialty hospital in KIDWAI (Kidwai Memorial Institute of Oncology) Bangalore. A sample of 300 caregivers of persons with cancer was selected based on simple random sampling, and with inclusion and exclusion criteria. Those patients satisfying the inclusion and exclusion criteria and attending both outpatient and inpatient services of cancer specialty hospital in KIDWAI Bangalore, Karnataka were selected randomly.Based on the pilot information regarding number of inpatient and outpatient at the KIDWAI centers in Bangalore random numbers was taken care of the patient load at the given center. The data was collected from the patients \& caregivers of persons living with cancer who fulfill the inclusion/exclusion criteria were taken up for the study after their consent. Hospital registration number during the study period was used to obtain a representative random sample. A semi structured interview schedule and other research instrument, The Coping Check List was administered to understand the coping pattern. The interviews and the instruments were administered by research experts.

\section{RESULT}

Table 1: Socio demographic variables

\begin{tabular}{|l|l|l|}
\hline Variables & Frequency & Percentage \\
\hline Gender & 191 & $63.7 \%$ \\
\hline Male & 109 & $36.3 \%$ \\
\hline Female & 57 & $19.0 \%$ \\
\hline Marital status & 240 & $80.0 \%$ \\
\hline Single & 2 & $0.7 \%$ \\
\hline Married & 1 & $0.3 \%$ \\
\hline Divorced & \multicolumn{2}{|l|}{} \\
\hline Separated & 265 & $88.3 \%$ \\
\hline Religion & 28 & $9.3 \%$ \\
\hline Hindu & 7 & $2.3 \%$ \\
\hline Muslim & \multicolumn{2}{|l}{} \\
\hline Christian & 185 & $61.7 \%$ \\
\hline Domicile & 102 & $34.0 \%$ \\
\hline Rural &
\end{tabular}




\begin{tabular}{|l|l|l|}
\hline \multicolumn{2}{|l|}{ Semi-urban } & \multicolumn{2}{l|}{} & $4.3 \%$ \\
\hline Occupation & \multicolumn{2}{l|}{} \\
\hline Housewife & 61 & $20.3 \%$ \\
\hline Teacher & 9 & $3.0 \%$ \\
\hline Farmer & 58 & $19.3 \%$ \\
\hline Service & 3 & $1.0 \%$ \\
\hline Domestic help & 7 & $2.3 \%$ \\
\hline Business & 16 & $5.3 \%$ \\
\hline Professional & 3 & $1.0 \%$ \\
\hline Others & 143 & $47.7 \%$ \\
\hline Qualification & \multicolumn{2}{|l|}{} \\
\hline Illiteracy & 40 & $13.3 \%$ \\
\hline Primary & 169 & $56.3 \%$ \\
\hline Secondary & 36 & $12.0 \%$ \\
\hline Graduate & 49 & $16.3 \%$ \\
\hline PG & 6 & $2.0 \%$ \\
& & \\
\hline
\end{tabular}

The study sample consists of $\mathrm{N}=191(63.7 \%)$ males and $\mathrm{N}=109$ (36.6\%) females,

The distribution of marital status as single, married, divorced, and separated ration was $57: 240: 2: 1$ with majority $80 \%(\mathrm{~N}=240)$ of the caregivers belonging to married category $19 \%(\mathrm{~N}$ $=57)$ of the caregivers were unmarried, , 0.7\% $(\mathrm{N}=2)$ of the caregivers belonging to divorced category, and the remaining $0.3 \%(\mathrm{~N}=1)$ of the caregivers were separated.

The distribution of religion of caregivers as Hindu, Islam, Christianity, with a majority of $88.3 \%$ $(\mathrm{N}=265)$ of the caregivers followed the Hindu religion, 9.3\% $(\mathrm{N}=28)$ of the caregivers followed Islam, and the remaining $2.3 \%(\mathrm{~N}=7)$ of the caregivers followed Christianity.

The distribution of domicile of caregivers asthe majority of caregivers hailing from Rural areas $(\mathrm{N}=185,61.7 \%)$, from Urban areas $(\mathrm{N}=102,34.0 \%)$ and the remaining were $4.3 \%(\mathrm{~N}=13)$ of the caregivers belonging to semi urban area.

The study sample consists majority of the caregivers were employed in other kinds of work such as auto drivers, tailors and students, $47.7 \%(\mathrm{~N}=143)$, while 20.3\% ( $\mathrm{N}=61)$,were house wife, $19.3 \%(\mathrm{~N}=58)$,were employed in agriculture, $5.3 \%(\mathrm{~N}=16)$, of them had businesses, $3 \%(\mathrm{~N}=9)$, were teachers, $2.3 \%(\mathrm{~N}=7)$, of the caregivers were employed as domestic helps and the remaining $1 \%(\mathrm{~N}=3)$, of the caregivers were employed in the service sector, $1 \%(\mathrm{~N}=3)$, of the caregivers were employed as professionals.

The study sample consists majority of the respondents were completed, their primary level (class 1 to $7^{\text {th }}$ standard) $56.3 \%(\mathrm{~N}=169)$, while $16.3 \%(\mathrm{~N}=49)$, were graduates, $13.3 \%(\mathrm{~N}=40)$, of the respondents were illiterate, $12 \%(\mathrm{~N}=36)$, were completed up to secondary level (Class $8^{\text {th }}$ to Class $\left.10^{\text {th }}\right)$ and the remaining $2 \%(\mathrm{~N}=6)$, were completed their post graduate level. 
Table 2: Clinical details of caregivers of cancer patients

\begin{tabular}{|c|c|c|c|c|c|}
\hline $\begin{array}{l}\text { Variable } \\
\text { s }\end{array}$ & $\begin{array}{l}\text { Frequenc } \\
\mathbf{y}\end{array}$ & Percentage & variables & Frequency & Percentage \\
\hline \multicolumn{3}{|c|}{ Causative factors for cancer } & \multicolumn{3}{|c|}{ Relationship of informant } \\
\hline Tobacco & 151 & $50.3 \%$ & Parents & 26 & $8.7 \%$ \\
\hline Alcohol & 64 & $21.3 \%$ & Siblings & 36 & $12.0 \%$ \\
\hline Smoking & 86 & $28.7 \%$ & Children & 133 & $44.3 \%$ \\
\hline Stress & 9 & $3.0 \%$ & Spouse & 77 & $25.7 \%$ \\
\hline Lifestyle & 112 & $37.3 \%$ & Others & 28 & $9.3 \%$ \\
\hline $\begin{array}{l}\text { Family } \\
\text { History }\end{array}$ & 43 & $14.3 \%$ & \multicolumn{3}{|l|}{ Referred by } \\
\hline Radiation & 1 & $0.3 \%$ & Direct & 17 & $5.7 \%$ \\
\hline Pills & 2 & $0.7 \%$ & Govt. hospital & 145 & $48.3 \%$ \\
\hline $\begin{array}{l}\text { Food } \\
\text { habit } \\
\text { Spicy } \\
\text { food } \\
\text { Green } \\
\text { chilly) }\end{array}$ & 14 & $4.7 \%$ & $\begin{array}{l}\text { Private } \\
\text { hospital }\end{array}$ & 136 & $45.3 \%$ \\
\hline $\begin{array}{l}\text { (Hepatitis } \\
\text { B) } \\
\text { h/jaundic } \\
\text { e }\end{array}$ & 2 & $0.7 \%$ & Others & 2 & $0.7 \%$ \\
\hline \multicolumn{3}{|c|}{ Number of cancer symptoms } & \multicolumn{3}{|c|}{ Nature of treatment } \\
\hline One & 158 & $52.7 \%$ & $\begin{array}{l}\text { Biopsy } \\
\text { Investigation }\end{array}$ & 3 & $1.0 \%$ \\
\hline Two & 103 & $34.3 \%$ & $\begin{array}{l}\text { Medical } \\
\text { Management }\end{array}$ & 3 & $1.0 \%$ \\
\hline Three & 30 & $10.0 \%$ & Palliative care & 32 & $10.7 \%$ \\
\hline Four & 7 & $2.3 \%$ & Radiotherapy & 1 & $0.3 \%$ \\
\hline Five & 2 & $0.7 \%$ & Surgery & 261 & $87.0 \%$ \\
\hline \multicolumn{6}{|c|}{ Place of residence } \\
\hline $\begin{array}{l}\text { Bangalor } \\
\text { e city }\end{array}$ & 84 & 28.0 & & & \\
\hline $\begin{array}{l}\text { Other } \\
\text { parts of } \\
\text { Karnatak } \\
\text { a }\end{array}$ & 199 & 66.3 & & & \\
\hline Others & 17 & 5.7 & & & \\
\hline
\end{tabular}


The distribution of causative factor for cancer as the majority of the caregivers opinion regarding the causative factor for cancer were use of tobacco $50.3 \%(\mathrm{~N}=151)$, while $37.3 \%(\mathrm{~N}=112)$, were reported as life style $28.7 \%(\mathrm{~N}=86)$, were reported as smoking, $21.3 \%(\mathrm{~N}=64)$, were reported as alcohol and $14.3 \%(\mathrm{~N}=43)$, were reported family history as a causative factor.

And above table describes the number of cancer symptoms the caregivers were able to identify in themselves. 52.7\% $(\mathrm{N}=158)$ reported that they had one symptom, 34.3\% $(\mathrm{N}=103)$ reported that they had two symptoms, $10 \%(\mathrm{~N}=30)$ of the caregivers reported that they had three symptoms, $2.3 \%(\mathrm{~N}=7)$ reported that they had four symptoms and $0.7 \%(\mathrm{~N}=2)$ reported that they could identify five symptoms in them.

The majority of the caregivers of cancer patients $66.3 \%(\mathrm{~N}=199)$ came from other parts of Karnataka, 28\% ( $\mathrm{N}=84)$ caregivers of cancer patients were coming from Bangalore city, and The rest of the $5.7 \%(\mathrm{~N}=17)$ caregivers of cancer patients were coming from other parts of India.

The majority of the cancer patient informants were children, $44.3 \%(\mathrm{~N}=133)$, while $25.7 \%$ $(\mathrm{N}=77)$, were spouse, $12 \%(\mathrm{~N}=36)$, belonged sibling, $8.7 \%(\mathrm{~N}=26)$, belonged parents and the rest of them $9.3 \%(\mathrm{~N}=28)$ belonged others informants such as father in law, mother in law, brother in law, sister in law etc.

This table shows that $48.3 \%(\mathrm{~N}=145)$, of the patients were referred by government hospital, $45.3 \%(\mathrm{~N}=136)$, of the patients were referred by private hospitals, and remaining $5.7 \%(\mathrm{~N}=17)$, of the caregivers were visited KIDWAI hospital directly.

The above table highlights the nature of the cancer treatment. The result shows that the $87 \%$ $(\mathrm{N}=261)$, of the caregivers have undergone surgery, $10.7 \%(\mathrm{~N}=32)$, of the caregivers have undergone palliative care, and $1 \%(\mathrm{~N}=3)$, of the caregivers have undergone biopsy investigation, medical management and radiotherapy.

Table 3: Comparison of coping checklist scale between male and female

\begin{tabular}{|l|l|l|l|l|}
\hline Variables & $\begin{array}{l}\text { Male (n= 191 ) } \\
\text { Mean (SD) }\end{array}$ & $\begin{array}{l}\text { Female(n= 109) } \\
\text { Mean (SD) }\end{array}$ & U Score & P value \\
\hline Cop Problem solving & $3.72(1.67)$ & $3.33(1.83)$ & -1.937 & $0.053^{*}$ \\
\hline $\begin{array}{l}\text { Cop Distraction } \\
\text { positive }\end{array}$ & $2.89(1.94)$ & $2.43(2.05)$ & -2.483 & $0.013^{*}$ \\
\hline $\begin{array}{l}\text { Cop Distraction } \\
\text { negative }\end{array}$ & $2.72(1.30)$ & $1.77(1.00)$ & -6.315 & $\begin{array}{l}<0.001^{*} \\
*\end{array}$ \\
\hline Cop Acceptance & $3.37(2.21)$ & $2.57(1.97)$ & -3.031 & $0.002^{*}$ \\
\hline Cop Religion & $2.93(1.45)$ & $3.17(1.55)$ & -1.691 & 0.091 \\
\hline Cop Denial & $2.94(1.55)$ & $2.80(1.61)$ & -1.072 & 0.284 \\
\hline \begin{tabular}{l} 
Cop Social support \\
\hline
\end{tabular} & $3.62(1.20)$ & $3.08(1.20)$ & -4.358 & $\begin{array}{l}<0.001^{*} \\
*\end{array}$ \\
\hline
\end{tabular}

Mann-Whitney U test was used to compare the coping checklist is to find out how people deal with or handle difficult situations faced by the male and female caregivers. The result indicates 
that Problem solving, Distraction positive, Distractions negative, Acceptance domain, and social support domain of coping was significantly different with males were greater than females which was statistically significant.

No significant difference was found among other domains such as Religion of coping and Denial style of coping.

Table 4: Comparison of coping checklist scale between single and married

\begin{tabular}{|l|l|l|l|l|}
\hline Variables & $\begin{array}{l}\text { Single (n= 59 ) } \\
\text { Mean (SD) }\end{array}$ & $\begin{array}{l}\text { Married (n= 241) } \\
\text { Mean (SD) }\end{array}$ & U Score & P value \\
\hline $\begin{array}{l}\text { Cop Problem } \\
\text { solving }\end{array}$ & $3.76(1.71)$ & $3.53(1.74)$ & -0.920 & 0.357 \\
\hline $\begin{array}{l}\text { Cop Distraction } \\
\text { positive }\end{array}$ & $3.40(2.45)$ & $2.56(1.82)$ & -2.311 & $0.021^{*}$ \\
\hline $\begin{array}{l}\text { Cop Distraction } \\
\text { negative }\end{array}$ & $1.67(1.19)$ & $2.55(1.25)$ & -5.267 & $<0.001^{* *}$ \\
\hline Cop Acceptance & $3.74(2.36)$ & $2.92(2.08)$ & -2.423 & $0.015^{*}$ \\
\hline Cop Religion & $3.33(1.63)$ & $2.94(1.44)$ & -1.917 & 0.055 \\
\hline Cop Denial & $2.94(1.66)$ & $2.87(1.55)$ & -0.146 & 0.884 \\
\hline Cop Social support & $3.72(1.17)$ & $3.35(1.23)$ & -2.489 & $0.013^{*}$ \\
\hline
\end{tabular}

Mann-Whitney U test was used to compare the coping checklist to find out how people deal with or handle difficult situations faced by the single and married caregivers with cancer patients. The result indicates that Distraction positive, Social support and Acceptance of coping was significantly differing with single caregivers were greater than married caregivers which was statistically significant. Distraction negative of coping was significantly differing with married caregivers were greater than single caregivers which was statistically significant.

No significant difference was found among other domains such as Problem solving of coping Religion of coping and Denial.

Table 5: Comparison of coping checklist scale between Hindu and Other Religion

\begin{tabular}{|l|l|l|l|l|}
\hline Variables & $\begin{array}{l}\text { Hindu } \\
(\mathbf{n = 2 6 5}) \\
\text { Mean (SD) }\end{array}$ & $\begin{array}{l}\text { Other Religion (n= } \\
\text { 35) } \\
\text { Mean (SD) }\end{array}$ & U Score & P value \\
\hline $\begin{array}{l}\text { Cop } \\
\text { Problem } \\
\text { solving }\end{array}$ & $3.66(1.72)$ & $3.0(1.74)$ & -2.295 & $0.022^{*}$ \\
\hline $\begin{array}{l}\text { Cop } \\
\text { Distraction } \\
\text { positive }\end{array}$ & $2.73(1.96)$ & $2.68(2.17)$ & -0.290 & 0.771 \\
\hline $\begin{array}{l}\text { Cop } \\
\text { Distraction } \\
\text { negative }\end{array}$ & $2.37(1.29)$ & $2.42(1.28)$ & -0.326 & 0.744 \\
\hline $\begin{array}{l}\text { Cop } \\
\text { Acceptance }\end{array}$ & $3.10(2.16)$ & $2.97(2.17)$ & -0.167 & 0.867 \\
\hline Cop & $3.04(1.45)$ & $2.85(1.73)$ & -1.391 & 0.164 \\
\hline
\end{tabular}




\begin{tabular}{|l|l|l|l|l|}
\hline Religion & & & & \\
\hline Cop Denial & $2.91(1.58)$ & $2.71(1.48)$ & -0.577 & 0.564 \\
\hline $\begin{array}{l}\text { Cop Social } \\
\text { support }\end{array}$ & $3.49(1.19)$ & $2.94(1.39)$ & -2.526 & $0.012 *$ \\
\hline
\end{tabular}

Mann-Whitney U test was used to compare the coping checklist to find out how people deal with or handle difficult situations faced by the Hindu and Other Religion caregivers with cancer patients. The result indicates that Problem solving and Social support of coping was significantly differing with Hindu religion caregivers were greater than other religion caregivers which was statistically significant.

No significant difference was found among other domains

Table 6: Comparison of coping checklist scale between caregivers of cancer patients underwent surgery and other modes of treatment

\begin{tabular}{|l|l|l|l|l|}
\hline Variables & $\begin{array}{l}\text { Surgery (n= 261) } \\
\text { Mean (SD) }\end{array}$ & $\begin{array}{l}\text { Other treatment }(\mathbf{n = 3 9}) \\
\text { Mean (SD) }\end{array}$ & U Score & P value \\
\hline $\begin{array}{l}\text { Cop Problem } \\
\text { solving }\end{array}$ & $3.55(1.76)$ & $3.76(1.58)$ & -0.844 & 0.398 \\
\hline $\begin{array}{l}\text { Cop Distraction } \\
\text { positive }\end{array}$ & $2.64(1.94)$ & $3.25(2.20)$ & -1.561 & 0.118 \\
\hline $\begin{array}{l}\text { Cop Distraction } \\
\text { negative }\end{array}$ & $2.38(1.23)$ & $2.35(1.59)$ & -0.518 & 0.604 \\
\hline Cop Acceptance & $3.02(2.14)$ & $3.51(2.25)$ & -1.263 & 0.207 \\
\hline Cop Religion & $2.90(1.41)$ & $3.79(1.73)$ & -3.800 & $<0.001^{* *}$ \\
\hline Cop Denial & $2.78(1.45)$ & $3.61(2.09)$ & -3.800 & $<0.001^{* *}$ \\
\hline $\begin{array}{l}\text { Cop Social } \\
\text { support }\end{array}$ & $3.40(1.21)$ & $3.58(1.29)$ & -1.083 & 0.279 \\
\hline
\end{tabular}

Mann-Whitney U test was used to compare the coping checklist to find out how people deal with or handle difficult situations faced by the caregivers of cancer patients underwent surgery and other modes of treatment. The result indicates that Religion of coping was significantly differing with caregivers cancer of other modes of treatment were greater than caregivers of cancer patients underwent surgery which was statistically significant. Denial of coping was significantly differing with caregivers cancer of other modes of treatment were greater than caregivers of cancer patients underwent surgery which was statistically significant.

No significant difference was found among other domains.

Table 7: Comparison of coping checklist scale between caregivers of cancer patients whether they had taken treatment or not

\begin{tabular}{|l|l|l|l|l|}
\hline Variables & $\begin{array}{l}\text { Treatment }(\mathbf{n}=49) \\
\text { Mean }(\mathbf{S D})\end{array}$ & $\begin{array}{l}\text { No treatment }(\mathbf{n}=\mathbf{2 5 1}) \\
\text { Mean (SD) }\end{array}$ & U Score & P value \\
\hline $\begin{array}{l}\text { Cop } \\
\text { Problem } \\
\text { solving }\end{array}$ & $3.71(1.62)$ & $3.55(1.76)$ & -0.832 & 0.405 \\
\hline Cop & $2.61(2.06)$ & $2.74(1.97)$ & -0.641 & 0.522 \\
\hline
\end{tabular}




\begin{tabular}{|l|l|l|l|l|}
\hline $\begin{array}{l}\text { Distraction } \\
\text { positive }\end{array}$ & & $2.40(1.19)$ & -1.342 & 0.179 \\
\hline $\begin{array}{l}\text { Cop } \\
\text { Distraction } \\
\text { negative }\end{array}$ & $2.24(1.71)$ & $3.11(2.18)$ & -0.585 & 0.559 \\
\hline $\begin{array}{l}\text { Cop } \\
\text { Acceptance }\end{array}$ & $2.93(2.05)$ & $3.03(1.52)$ & -0.027 & 0.979 \\
\hline $\begin{array}{l}\text { Cop } \\
\text { Religion }\end{array}$ & $2.93(1.32)$ & $2.88(1.59)$ & -0.262 & 0.793 \\
\hline Cop Denial & $2.95(1.51)$ & $3.42(1.22)$ & -0.531 & 0.596 \\
\hline $\begin{array}{l}\text { Cop Social } \\
\text { support }\end{array}$ & $3.46(1.24)$ & & & \\
\hline
\end{tabular}

Mann-Whitney U test was used to compare the coping checklist to find out how people deal with or handle difficult situations faced by the caregivers of cancer patients had taken treatment and they not have taken treatment. The result indicates the there was no significant difference between the group domains.

Table 8: Comparison of coping checklist scale between caregivers according to education

\begin{tabular}{|l|l|l|l|l|l|l|}
\hline $\begin{array}{l}\text { Variab } \\
\text { les }\end{array}$ & $\begin{array}{l}\text { Illiterate(n } \\
\text { =40) } \\
\text { Mean (SD) }\end{array}$ & $\begin{array}{l}\text { Primary(n= } \\
\text { 169) } \\
\text { Mean (SD) }\end{array}$ & $\begin{array}{l}\text { Secondary(n } \\
\text { =36) } \\
\text { Mean (SD) }\end{array}$ & $\begin{array}{l}\text { Graduate(n } \\
\mathbf{5 5}) \\
\text { Mean (SD) }\end{array}$ & $\begin{array}{l}\text { UFSco } \\
\text { re }\end{array}$ & P value \\
\hline $\begin{array}{l}\text { Cop } \\
\text { Proble } \\
\text { m } \\
\text { solving }\end{array}$ & $2.47(1.19)$ & $3.30(1.45)$ & $4.02(1.90)$ & $4.94(1.91)$ & 52.757 & $\begin{array}{l}<0.001 \\
* *\end{array}$ \\
\hline $\begin{array}{l}\text { Cop } \\
\text { Distract } \\
\text { ion } \\
\text { positive }\end{array}$ & $1.57(1.31)$ & $2.37(1.63)$ & $3.69(2.35)$ & $4.00(2.27)$ & 43.633 & $\begin{array}{l}<0.001 \\
* *\end{array}$ \\
\hline $\begin{array}{l}\text { Cop } \\
\text { Distract } \\
\text { ion } \\
\text { negativ } \\
\text { e }\end{array}$ & $2.00(1.21)$ & $2.50(1.23)$ & $2.44(1.36)$ & $2.21(1.39)$ & 7.854 & $0.049 *$ \\
\hline $\begin{array}{l}\text { Cop } \\
\text { Accept } \\
\text { ance }\end{array}$ & $1.75(1.23)$ & $2.86(1.99)$ & $4.02(2.65)$ & $4.12(2.15)$ & 36.401 & $\begin{array}{l}<0.001 \\
* *\end{array}$ \\
\hline $\begin{array}{l}\text { Cop } \\
\text { Religio } \\
\mathrm{n}\end{array}$ & $2.75(1.40)$ & $2.84(1.38)$ & $3.19(1.67)$ & $3.63(1.57)$ & 19.980 & $\begin{array}{l}<0.001 \\
* *\end{array}$ \\
\hline $\begin{array}{l}\text { Cop } \\
\text { Denial }\end{array}$ & $2.72(1.60)$ & $2.91(1.44)$ & $2.91(1.99)$ & $2.94(1.68)$ & 2.490 & $0.477 *$ \\
\hline $\begin{array}{l}\text { Cop } \\
\text { Social } \\
\text { support }\end{array}$ & $2.60(1.33)$ & $3.35(1.16)$ & $3.72(1.05)$ & $4.07(1.051)$ & 38.571 & $\begin{array}{l}<0.001 \\
* *\end{array}$ \\
\hline
\end{tabular}


ANOVA test was used to compare the coping checklist to find out how people deal with or handle difficult situations faced by the caregivers of cancer patient's qualification. It indicates that illiterate caregivers of cancer patients and other qualification of cancer caregivers were significantly differing with illiterate caregivers of cancer patients having a significantly higher burden compared to other qualification such as primary, secondary, graduate caregivers of cancer patients to the following domain such as coping of Problem solving, coping of Distraction positive, coping of Acceptance, coping of Religion, coping of Denial, and coping of Social support.

\section{DISCUSSION}

\section{COMPARISON BETWEEN COPING CHECKLIST SCALE AND DEPENDENT VARIABLES}

The current result indicates that Problem solving, Distraction positive, Distractions negative, Acceptance and social support domain of coping was significantly different with males were greater than females which was statistically significant. Hagedoorn (2008) reported that Results about the differential effects of gender on patient and caregiver distress are mixed, but a recent meta-analysis has indicated that regardless of role (i.e. patient or caregiver), women are more distressed by cancer than men. But in contradiction to this current result with previous research found main effects (with no interactions) of gender on the use of several coping styles. Women were more likely than men to use instrumental support, religious coping, and emotional support. These findings support previous research that has found gender differences in parental coping after a pediatric cancer diagnosis (Grootenhuis \& Last, 1997). For example, mothers have been found to report more frequent and more effective coping compared with fathers (Goldbeck, 2001). Hoekstra-Weebers et al. (2011) found that mothers' use of a passive reaction pattern and support seeking placed them at increased risk for psychological distress in the first year after their child's cancer diagnosis, while fathers' were at increased risk for distress when their coping styles included avoidance, a passive reaction pattern, expression of emotions, and decreased active problem focusing. Our findings contribute further insight into gender differences in caregiver coping, expanding our knowledge of how gender and education interact. In particular, men with lower levels of education may be at risk for higher substance use coping and lower planning coping. Our results also show that women were more likely to engage in several active coping behaviors such as seeking instrumental support. Women were also more likely to use religion and seek emotional support while coping with their child's cancer diagnosis. These findings are consistent with other studies which have found that women and men perceive different role expectations related to their child's cancer diagnosis (Chesler \& Parry, 2001; Goldbeck, 2001) and that women are more likely to engage in support seeking after a pediatric cancer diagnosis (Hoekstra-Weelbers et al., 2011). It may be that women perceive more responsibility for the direct management of their child's cancer care and are therefore more likely to engage in these active coping styles. Women may also be in established patterns of seeking emotional support from their networks and may feel more comfortable seeking this support after their child's cancer diagnosis. This study also indicates that Distraction positive, Acceptance and Social support of coping was significantly differs with single caregivers were greater than married caregivers which was statistically significant. Distraction negative of coping was significantly differs with married caregivers were greater than single caregivers which was statistically significant. Regarding religion it indicates that Problem solving and Social support 
of coping was significantly differs with Hindu religion caregivers were greater than other religion caregivers which was statistically significant. .

The result indicates that Problem solving of coping was significantly differs with the person's heard about cancer caregivers were greater than person's not hearing about cancer, which was statistically significant. Distraction positive, Distraction negative and Social support of coping was significantly differs person's heard about cancer caregivers were greater than the person's not hearing about cancer, which was statistically significant. Acceptance of coping was significantly differs with person's heard about cancer having significantly higher burden compared to the person's not hearing about cancer.

The result also indicates that illiterate caregivers of cancer patients and other qualification of cancer caregivers were significantly differing with each other. Illiterate caregivers of cancer patients having a significantly higher burden compared to other qualification such as primary, secondary, graduate caregivers of cancer patients to the following domain such as coping of Problem solving, coping of Distraction positive, coping of Acceptance, coping of Religion, coping of Denial, and coping of Social support. Caregiver educational attainment was positively associated with use of planning and active coping styles, while income was not associated with caregiver coping style. Mothers were more likely than fathers to use active coping, instrumental support, religious coping, and emotional support. Men with lower education engaged in greater substance use coping and lower planning. The findings show that educational attainment and caregiver gender influence caregiver coping styles following a pediatric cancer diagnosis and suggest that educational attainment rather than financial resources drive the association between SES and coping. Programs that address educational gaps and teach caregivers planning and active coping skills may be beneficial for parents with lower educational attainment, particularly men (Elizabeth, 2013).

\section{CONCLUSION}

This study concluded that there was poor coping were found in female caregivers, illiterate caregivers, caregivers of cancer patients underwent surgery, the person's not hearing about cancer, and other religion caregivers. So, it is imperative to design suitable intervention strategies to enhance the coping and other psychosocial issues of caregivers of patients living with cancer. Family caregivers are critical partners in the plan of care for patients with chronic illnesses. Improvement can be obtained through communication and caregiver support to strengthen caregiver competency and teach caregivers new skills that will enhance patient safety. There is more to be learned about the effect of family caregivers on patient outcomes and areas of concern for patient safety. Social worker continue to play an important role in helping family caregivers become more confident and competent providers as they engage in the health care process.

\section{ACKNOWLEDGEMENTS}

This study is funded by ICSSR (Indian Council of Social Science Research) New Delhi. 


\section{REFERENCES}

[1] Chesler MA, Parry C. Gender roles and/or styles in crisis: An integrative analysis of the experiences of fathers of children with cancer. Qualitative Health Research. 2001; 11:363-384.

[2] Elizabeth, A. Gage-Bouchard, Katie, A. Devine, \& Charles E. Heckler (2013). The Relationship between Socio-demographic Characteristics, Family Environment, and Caregiver Coping in Families of Children with Cancer, Journal of Clinical Psychology. 20 (4).

[3] Goldbeck L. Parental coping with the diagnosis of childhood cancer: Gender effects, dissimilarity within couples, and quality of life. Psycho-Oncology. 2001; 10:325-335.

[4] Goldbeck L. Parental coping with the diagnosis of childhood cancer: Gender effects, dissimilarity within couples, and quality of life. Psycho-Oncology. 2001; 10:325-335.

[5] Grootenhuis MA, Last BF. Adjustment and coping by parents of children with cancer: A review of the literature. Supportive Care in Cancer. 1997; 5:466-484.

[6] Hagedoorn M., Sanderman R., Bolks H. N., Tuinstra J., Coyne J. C. (2008). "Distress in couples coping with cancer: A meta-analysis and critical review of role and gender effects".Psychological Bulletin 134 (1): 1-30

[7] Hoekstra-Weebers JEHM, Wijnberb-Williams BJ, Jaspers JPC, Kamps WA, van de Wiel HBM. Coping and its effect on psychological distress of parents of pediatric cancer patients: a longitudinal prospective study. Psycho-Oncology. 2011.

[8] Pearce, M.J, Singer, J., Prigerson, H. G. (2006). Religious coping among caregivers of terminally ill cancer patients: main effects and psychosocial mediators. J Health Psychol. 2006 Sep;11(5):743-59. 